\title{
The Effect On Wage Of Attending A US News And World Report Best College
}

Stephanie Owings-Edwards, (Email Owings_S@FortLewis.edu), Fort Lewis College

\begin{abstract}
A great deal of attention is paid to the annual release of the U.S. News and World Report college rankings. According to national surveys of college freshman, enhanced earning potential is a major motivator in their choosing to attend college and in their selecting which college to attend. Thus you would expect the U.S. News and World Report rankings to be highly correlated with those institutions whose students earn a wage premium. This paper uses the data set High School and Beyond to test the effect on wage of attending a college identified by U.S. News and World Report as a "best college." I find no statistically significant relationship between attending a U.S. News and World Report "best college" and wage earned.
\end{abstract}

\section{INTRODUCTION}

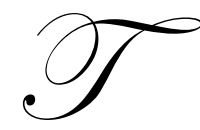

he release of U.S. News and World Report's annual college rankings has become one of the rites of fall. It is one of the magazine's top selling issues, reaching approximately 12 million readers. U.S. News publishes a college guide based on these rankings which sells more copies than any other college review.

Highly rated schools often issue press releases announcing their status as a U.S. News Best College. Colleges say appearing on a U.S. News Best College list increases the level of alumni donations and the quality of applicants. The real effect of a school's ranking is confirmed by Monks and Ehrenberg (1999). They consider U.S. News and World Report top ranked national universities and liberal arts colleges. They find a decline in ranking (ie. dropping from $4^{\text {th }}$ to $5^{\text {th }}$ ) causes an increase in the school's admit rate (the number of students admitted/the number of applicants), a decline in yield (number of matriculants /number of admitted students), and a decline in the average SAT score of the institution's incoming freshmen class.

According to a Wall Street Journal exposé (April 5, 1995), many college administrators were so eager to be highly ranked that they falsified the statistics they supplied to U.S. News and World Report. The Wall Street Journal compared average SAT scores, acceptance rates, and graduation rates which colleges provided to credit rating agencies with those they provided to college guides. If a school wants to issue bonds it must provide accurate information to a credit rating agency. If it falsifies this information it is in violation of federal securities laws and can be held legally liable. Hence there is every reason to believe the information supplied to credit rating agencies is accurate. The Wall Street Journal reviewed over 100 college credit reports and compared them with college guidebook statistics. They found a $25 \%$ discrepancy rate and the credit report numbers were almost always the less flattering. The next U.S. News and World Report, issued 5 months after the initial Wall Street Journal revelations, still had over 160 schools reporting incomplete and inaccurate numbers.

Every fall since 1966 the Cooperative Institutional Research Program has collected survey data from entering freshmen. In 1982, the year the observations in this study graduated from high school, $69.8 \%$ of the polled students stated making more money was an important factor in their deciding to attend college. This was the $3^{\text {rd }}$ most frequently cited reason for going to college. The most commonly mentioned (77.9\%) reason for attending college was "to be able to get a better job." The most frequently cited (69\%) "Essential or very important objective" of 1982 freshmen was to "be very well-off financially." Nearly $50 \%$ of them chose the specific college they were attending 
because the school's "graduates get good jobs." Thus, for the U.S. News and World Report rankings to have relevance to a college freshman, the rankings should identify those institutions whose students earn a wage premium.

This paper tests the effect on wages of attending a college identified by U.S. News and World Report as a "best college." I use the longitudinal, time series study High School and Beyond as my data set. This study gathered information on individuals who were high school sophomores in 1980. Twelve years later income information was collected from the original participants. I find no statistically significant relationship between attending a U.S. News and World Report "best college" and wage earned.

\section{BACKGROUND}

There are several studies which have used the data set High School and Beyond to test the relationship between specific college characteristics and post-college earnings.

Marc Fox (1993) considers those in High School and Beyond who were high school seniors in 1980 and who had completed college by 1986 . He tests the relationship between the wage they earned in 1986 with the selectivity of the college from which they graduated while controlling for individual and family characteristics. His college selectivity measure is drawn from Barrons' Profiles of American Colleges. They group colleges into 6 categories according to selectivity. This selectivity measure incorporates entering students' class rank, high school GPA, average SAT score, and acceptance ratio. Fox considers a student to have attended a highly selective institution if he graduated from a school in the top two Barrons' categories. He finds there is a wage premium of $13 \%$ associated with attending a highly selective college.

Brewer, Eide, and Ehrenberg (1996) consider both the National Longitudinal Study of the High School Class of 1972 and the 1980 and 1982 high school seniors in High School and Beyond. They too make use of Barrons' Profiles of American Colleges and collapse the six selectivity categories into three ("elite," "middle," and "bottom"). Brewer et al further distinguish between schools based on control (public or private). Thus they create six categories of institutions: elite private, elite public, middle private, middle public, bottom private, bottom public. They find the members of the 1982 cohort who attended an elite private college earned a 37\% wage premium relative to those who attended bottom pubic institutions. They also control for the possibility that that students systematically select a particular college quality based on the expected labor market payoff. They find little evidence that this correction for college choice significantly affects their results.

Owings (1996) investigated the effect on wage of attending a research oriented university. Using the 1982 cohort of High School and Beyond, she found every $\$ 10,000$ increase in a college's research expenditures per faculty member increased the wages of those who attended the college by $4-5 \%$.

Other studies which have not made use of High School and Beyond have also documented a relationship between different measures of college quality and wages.

Loury and Garman (1995) make use of the National Longitudinal Study of the High School Class of 1972. They consider out-of-school males who received at least 1-years worth of education at a 4-year college. They find each 100 points added to the median SAT score of the college attended increased white earnings by $2.4 \%$ and black earnings by $5 \%$.

James et al (1989) also use the National Longitudinal Study of the High School Class of 1972 as their data set. They consider male, college graduates, working in 1985. They find attending a private eastern university, their proxy for a prestigious institution, earns a graduate an $8 \%$ wage premium. They also find that an institution's average SAT score matters; a 100 point increase in average SAT scores increases a graduate's wage by about $3 \%$.

A synopsis of early studies which tested the relationship between the earnings of those who attended a college and specific characteristics of that college can be found in Brewer and Ehrenberg (1996). These studies use a variety of college quality measures: faculty salaries, average SAT scores, subjective rankings, instructional 
expenditures, Carnegie classifications, measures of selectivity. Solomon (1975) showed a high degree of correlation between all of these quality measures. Most of the studies show a significant relationship between their measure of college quality and earnings (although this is unsurprising given the bias toward publishing only statistically significant findings). However, as Loury and Garman (1995) point out, most of these studies (Weisbrod \& Karpoff 1968; Wales 1973; Solomon 1975; Solomon \& Wachtel 1975; Wachtel 1976; Wise 1975) use white-male-only data sets. The exception to this is Morgan and Duncan (1979). They consider wages, of both men and women, earned in 1974, by individuals across a wide age spectrum. Although they find average ACT scores, expenditure per pupil, and Coleman prestige rankings all significantly affect male earnings, none of their college quality variables affect the earnings of women.

\section{DATA}

\section{High School \& Beyond}

My primary data source is the National Center for Education Statistics' longitudinal, time series study High School and Beyond. This study began in 1980, collecting data from over 30,000 high school sophomores. A second follow-up study was done in 1984. In this study only 18,500 individuals in the original sample were contacted. A fourth and final follow-up study was conducted in 1992. It contacted 14,825 members of the original sophomore cohort. Of these, 5,108 had attended a 4-year college.

High School and Beyond contains detailed individual, family, demographic and schooling characteristics of which I make use. An individual's SAT score, his high school GPA, and his college GPA are all included. The highest level of education achieved by either parent along with family income level in 1982 was collected. There is gender and race information. The drop-out rate of the high school an individual attended is available, as is the name of the college he attended and whether he graduated from that school.

Only annual income information, rather than hourly wage, was collected and that was only done in the 1992 follow-up survey. No information on hours or weeks worked was gathered.

A student who was a high school sophomore in 1980 who proceeded at a traditional pace would graduate from high school in 1982 and from college in 1986. Such a student would have 6 years of labor market experience at the time of the survey. Of those who attended a 4-year college only 4,165 had a reported income. Of these, only 1872 had complete files.

Note there are some schools which qualify as a U.S. News Best College but for which there are no observations. That is, the individuals in High School and Beyond did not, as a group, attend all of the schools designated as a best college.

\section{U.S. News \& World Report Rankings}

U.S. News began publishing college rankings in 1983. Initially, it was little more than a "beauty pageant." U.S. News polled college and university presidents and asked each to pick five schools providing the best undergraduate education from a list of colleges and universities similar to their own. The schools were divided into 4 lists which were roughly based on the Carnegie Foundation's classification of institutions of higher education.

The poll was repeated again in 1985. In 1987 the poll was expanded by asking the presidents to select ten top schools rather than five.

In 1988 U.S. News and World Report instituted a quantitative ranking system. They considered: each college's rejection rate, its average SAT or ACT, the percent of entering freshmen at the top of their high school class, the share of full-time professors with doctorates, the student-to-faculty ratio, the per-student instructional budget, the institution's endowment per student, the library budget per student, the percentage of freshmen who return as sophomores, the percentage of freshmen who graduate with a bachelor's degree in 4 years. 
Each of these attributes was converted to percentiles. The highest raw score was assigned a value of $100 \%$ and all other percentile scores were taken as a percentage of that top score. To determine a ranking, these percentiles were weighted according to a non-specified formula designed by U.S. News, and summed. Data came from the freshman class of 1987.

In the case of institutions which are classified by Carnegie as "National Universities" or "National LiberalArts Colleges", the national reputation of the school was also factored into the rankings formula. National reputation was determined by a U.S. News survey of college presidents, deans and admissions officers. Respondents were asked to place schools in their respective group into quartiles based on reputation for academic excellence.

In 1989, 1990, and 1991 U.S. News employed a similar, quantitative, ranking system. Weightings, when revealed, changed slightly as did some of the statistics considered. But the general methodology remained consistent.

However, over time, the categories into which schools were divided varied as did the category in which a school was placed, as did the number of ranked schools in any given category. Throughout the time period 1983-1991 three category labels did not change: National Universities, National Liberal Arts Colleges, and Regional Liberal Arts Colleges. However, in 1985 only 14 schools were listed as Top Liberal Arts Colleges whereas in 1987 twenty-six schools made the list. There was an identical $86 \%$ increase in the number of schools considered to be Top National Universities between 1985 and 1987. A fourth category was either labeled "Regional Colleges and Universities" (1989, 1990, 1991) or "Comprehensive Universities" and "Small Comprehensive Colleges" (1983, 1985, 1987, 1988). There were as many as 87 schools considered to be in this $4^{\text {th }}$ category (1985) and as few as 29 (1983). Some schools changed categories over time. Thus, Wesleyan was listed as a "National University" is 1985 however, in every other year, it was classified as a "National Liberal Arts College." Likewise, Washington and Lee University was considered to be a comprehensive college in 1983 but from 1987 on it was a top National Liberal Arts school.

A summary of each year's ranking criteria, the categories into which schools were distributed, and the number of schools in each category is found in Table 1, found at the end of the manuscript.

\section{EMPIRICAL APPROACH}

The empirical work of this paper is based on standard human capital theory. The model's dependent variable, logarithm of annual wage, is theorized to depend on: occupation, workforce \& job experience, current employment \& schooling status, family background, individual ability, race \& gender, characteristics of the college attended.

An individual's SAT score, his undergraduate GPA, and his high school GPA act to control for the contribution of individual ability to wage variation (see Griliches and Filer for a discussion on the issues involving individual ability in wage equations). Although these variables may display some multicollinearity, this only diminishes their individual significance. As I am only interested in controlling for individual ability and am not attempting to determine the effect of ability on wage, this issue of multicollinearity does not seem serious. The variables parental income, the highest level of education attained by either parent, and the drop-out rate of the high school the individual attended all reflect family background. The caveats which apply to the individual ability variables apply here as well.

\section{RESULTS}

Sample mean characteristics are shown in Table 2, found at the end of the manuscript. A comprehensive definition of each of the independent variables is found in Appendix 1, also located at the end of the manuscript.

Table 3, found at the end of the manuscript, reports a sub-set of the WLS regression results. ${ }^{1}$ The dependent variable is the natural logarithm of an individual's income. The full regression results may be obtained from the author

\footnotetext{
${ }^{1}$ The weight used was provided by the National Center for Education Statistics. According to NCES this weight compensates for the unequal probability of selection resulting from their intentional over-sampling. It was calculated so as to be appropriate for any observation who reported post-secondary attendance. Using OLS under these sampling circumstances leads to biased coefficient estimates.
} 
upon request.

\section{BASELINE}

Equation 1 is a standard earnings function without any college characteristics included. The results are typical of what other researchers have found. I find a wage premium of close to $27 \%\left(\mathrm{e}^{\wedge} .236-1\right)$ from earning an undergraduate degree. Likewise, Jaeger and Page (1996) estimated sheepskin effects of between $28 \%$ and $31 \%$ for Bachelor's degrees. The race variable BLACK is positive and significant. This corroborates the results of Belman and Heywood (1991) who showed a substantial wage premium was earned by black men, relative to white men, who had completed college. Loury and Garman (1995) compared black and white wage gains from increased SAT scores, GPA, and additional years of schooling. They found black men gained more, in terms of wage, than white men from an increase in any of these variables.

Equations 2 and 3 include specific college characteristics. Both of these variables were statistically significant at .01 level. Like Fox, James et al, and Brewer, Eide \& Ehrenberg, I find college control matters; column 2 shows attending a private, non-sectarian, college boosts earnings by more than $20 \%$ relative to a public university. Column 3 shows every $\$ 10,000$ increase in a college's research expenditures per faculty member increased the wages of those who attended the college by $3.5 \%$. Note that $\mathrm{N}$ is reduced by a little less than $10 \%$ in equation 3 because research expenditures were not available for all colleges in the data set.

\section{U.S. NEWS BEST COLLEGE VARIABLES}

Because of the change in methodology used by U.S. News to rank colleges between the periods 1983-1987 and 1988-1991 it is tempting to consider a school to be a "best college" only if it listed as such for each and every year, 1983-1991. However, that would exclude a school such as Wesleyan which was a highly ranked, "National Liberal Arts College," every year other than 1985 when it was deemed to be a "National University." To allow for such classification changes, I consider any college which made the list in at least 5 of the 7 years to be a superb school. Thus, to be classified as a superb school the college had to make the list both before and after the change in methodology. In Equation 4 all of the superb schools are grouped together ("best colleges") to determine if attending such a school yields a wage premium relative to all of the schools which were not US News ranked. In Equation 5 the US News ranked schools are broken into their respective categories. In neither case are the US News variables significant.

Between 1983 and 1991 thirty-six different schools appeared on the National University Best College list. Twenty-one (58\%) of these schools were mentioned in at least 5 of the 7 years. Over the same period, 33 different schools were mentioned on the National Liberal Arts list. Twenty of these schools (61\%) made the list in at least 5 of the 7 years. However, the regional liberal arts colleges and comprehensive colleges lists showed much less stability. There were 172 institutions which were classified as Best Comprehensive Colleges between 1983 and 1991. Only 27 of these schools (16\%) made U.S. News list for at least 5 of the 7 years. In fact, according to the rankings, only 1 of what was deemed the finest comprehensive schools in 1983 was still excellent in 1985. There were 93 different schools which were identified as a Best Regional Liberal Arts College somewhere between 1983 and 1991. Only 8 of these (9\%) made the U.S. News list for at least 5 of the 7 years. In fact, only 1 comprehensive college and 1 regional liberal arts college made the list in all 7 of the years considered. This compares with 11 National University schools which were on the list in each of the years and 8 National Liberal Arts Colleges which made the list every year.

Compounding this problem is the small number of observations in High School and Beyond who attended a liberal arts college, national or regional. If a best college is defined as a school which made the US News list in 5 of the 7 years then there are only 17 individuals who attended a Best National Liberal Arts College and only 3 individuals who attended a Regional Liberal Arts Best College. Even if the definition of a best college is expanded to include all schools which made the list in at least 2 of the 7 years there are only 18 individuals who attended a Regional Liberal Arts Best College and only 19 who attended a Best National Liberal Arts College. 
Taking these issues into consideration, an alternative specification is used in Equation 6. Neither national or regional liberal arts schools are considered. Because of the stability of the National University Best Colleges list, the dummy variable representing the best national universities remains defined as any school which made the list in at least 5 of the 7 years. This implies 58\% of the schools which made the list in any of the years are categorized as a Best National College. In order for a Best Comprehensive College to represent 58\% of all of the schools which ever made that list, its definition must be expanded to include any school which made the list in at least 2 of the 7 years. This specification change does not, however, result in either of the college variables being significant.

Another possible definition of a superb school would test to see if a student who entered college in a specific year attended any of the schools on the US News Best College list that year. The problem with using this approach for this sample is that it would grossly skew the results toward the beauty pageant years. Over 1000 of the observations (53\%) began college in 1982. Only 9\% of the students in this sample began college in 1988 or later. Yet it wasn't until 1988 that U.S. News began to rank schools quantitatively. To use a matching approach such as this and have the results pertain to current U.S. News measurements would require a younger sample.

It is particularly surprising that attending a school categorized as Best National University does not yield a wage premium. To corroborate this finding, I compare U.S. News Best National Universities to schools in their peer group. U.S. News defines National Universities as schools which "offer a full range of baccalaureate programs, are the leading granters of graduate degrees and perform extensive campus-based research." This is essentially identical to the definition of a Research University as provided by the Carnegie Classification of Institutions of Higher Education. In Equation 7, I consider only students who have attended Research I Universities. In Equation 8, I consider only students who have attended Research I or Research II Universities. Best National Universities remain defined as any school which appeared on the U.S. News list in at least 5 of the 7 years. Even when considering a universe composed exclusively of students who attended research institutions, attending what U.S. News deems the best of these research universities does not yield a wage premium.

\section{CONCLUSION}

Previous studies, as well as the initial regressions in this paper, have shown certain college characteristics do convey a wage premium. However, those characteristics do not appear to be reflected in the U.S. News Best Colleges rankings. Of course, when purchasing a college education a student is buying much more than future earning power. $\mathrm{He}$ is buying a network of contacts, a social setting, and an intellectual experience. Nonetheless, surveys indicate that entering freshman are still very concerned with the earning power a college education will net them. This begs the question of as to why the U.S. News rankings are regarded by so many as so important.

Perhaps college freshman, the group with expressed interest in a wage premium, are not the target audience of the US News rankings. In fact, only 7.4\% of 1998 entering freshman indicated an important reason in selecting the college they chose was its ranking in a national magazine. It may be that alumni, and the donative dollars which they represent, are the group which closely follows a college's rank status. This would explain the rankings' importance to administrators. It would not, however, explain why admissions applications increase when a school is listed by US News or why the quality of students applying increases as a result of a colleges being ranked by US News.

There is every reason to suspect college administrators were supplying US News and World Report with fallacious statistics prior to the Wall Street Journal expose. Although this might explain a set of rankings which did not, in fact, represent the best colleges in the US, it would not explain the continued popularity of the rankings. That is, it would explain the findings of this study but not why people continued to hold the report in such high regard.

It is, of course, possible that we have not yet reached a long run equilibrium. That is, eventually the public may come to regard the rankings as spurious at which time the report will lose the power and cache it holds today. But, if this is the case, it seems to be taking a disconcertingly long time for a rational public to adjust.

Another possibility is that those who attend superb schools work less. High School and Beyond only reports annual wage. It could be those student who attended a Best College earned a higher hourly wage than those who 
didn't but chose to work proportionately fewer hours. As a result, it appears that there is no wage gain from attending a superb school when, in fact, there is. However, there is no good intuitive explanation for why students who attended a Best College would choose to work less.

It also may be that the U.S. News rankings are too selective. That is, there may be some very fine schools, schools whose graduates earn a wage premium, that do not make regularly make the list. That would explain the insignificance of the U.S. News variable relative to earnings. Conversely, it may be that U.S. News rankings are too broad. Perhaps only a fraction of the schools on their list provide an education so superior that its graduates earn a wage premium.

Given the importance college freshmen place on the wage enhancing effects of a college education, a college ranking of greater interest would reflect the earnings premium conveyed by attending a specific institution. Tracy and Waldfogel (1997) have constructed such a list for U.S. business schools. Further research, applying their methodology at the undergraduate level, would be well received and could, quite possibly, reward its authors with entrepreneurial gains.

Table 1: Historical Outline of U.S. News' College Ranking Methodologies

\begin{tabular}{|c|l|l|}
\hline Year & \multicolumn{1}{|c|}{ Description } & \multicolumn{1}{|c|}{ Categories (\# of schools in each category) } \\
\hline 1983 & $\begin{array}{l}\text { Based on poll of university presidents who picked } \\
5 \text { top schools }\end{array}$ & $\begin{array}{l}\text { National Universities (14); National Liberal Arts (12); } \\
\text { Comprehensive Universities (29); Regional Liberal Arts (21) }\end{array}$ \\
\hline 1985 & $\begin{array}{l}\text { Based on poll of university presidents who picked } \\
5 \text { top schools }\end{array}$ & $\begin{array}{l}\text { National Universities (14); National Liberal Arts (14); } \\
\text { Comprehensive Institutions (87); Regional Liberal Arts (15) }\end{array}$ \\
\hline 1987 & $\begin{array}{l}\text { Based on poll of university presidents who picked } \\
10 \text { top schools }\end{array}$ & $\begin{array}{l}\text { National Universities (26); National Liberal Arts (26); } \\
\text { Comprehensive Colleges (44); Regional Liberal Arts (30) }\end{array}$ \\
\hline 1988 & Quantitative & $\begin{array}{l}\text { National Universities (25); National Liberal Arts (25); } \\
\text { Comprehensive Colleges (50); Regional Liberal Arts (25) }\end{array}$ \\
\hline 1989 & Quantitative & $\begin{array}{l}\text { National Universities (25); National Liberal Arts (25); } \\
\text { Regional Colleges (60); Regional Liberal Arts (40) }\end{array}$ \\
\hline 1990 & Quantitative & $\begin{array}{l}\text { National Universities (25); National Liberal Arts (25); } \\
\text { Regional Universities (60); Regional Liberal Arts (40) }\end{array}$ \\
\hline 1991 & Quantitative & $\begin{array}{l}\text { National Universities (25); National Liberal Arts (25); } \\
\text { Regional Universities (61); Regional Liberal Arts (40) }\end{array}$ \\
\hline
\end{tabular}


Table 2: Descriptive Statistics

\begin{tabular}{|c|c|c|c|}
\hline Variable & $\begin{array}{c}\text { Mean } \\
\text { (Standard } \\
\text { Deviation) } \\
\text { Equations 1-6 }\end{array}$ & $\begin{array}{c}\text { Mean } \\
\text { (Standard } \\
\text { Deviation) } \\
\text { Equation } 7\end{array}$ & $\begin{array}{c}\text { Mean } \\
\text { (Standard } \\
\text { Deviation) } \\
\text { Equation 8 }\end{array}$ \\
\hline National University $^{1}$ & $0.0266(.16)$ & $0.134(.34)$ & $0.094(.29)$ \\
\hline National Liberal Arts College ${ }^{1}$ & $0.009(.09)$ & & \\
\hline Regional Liberal Arts College $^{1}$ & $0.002(.04)$ & & \\
\hline Comprehensive College $^{1}$ & $0.020(.14)$ & & \\
\hline Comprehensive College $^{2}$ & $0.094(.29)$ & & \\
\hline Currently Unemployed & $0.063(.24)$ & $0.06(.24)$ & $0.073(.26)$ \\
\hline Currently in School & $0.139(.35)$ & $0.15(.36)$ & $0.144(.35)$ \\
\hline Personal SAT & $900.0(190)$ & $959.7(198.7)$ & $954.8(193.5)$ \\
\hline Undergraduate GPA & $2.773(.60)$ & $2.81(.56)$ & $2.79(.58)$ \\
\hline High School GPA & $3.06(1.15)$ & $2.83(1.1)$ & $2.86(1.1)$ \\
\hline Hispanic & $0.103(.30)$ & $0.145(.35)$ & $0.114(.32)$ \\
\hline Black & $0.103(.30)$ & $0.104(.31)$ & $0.113(.32)$ \\
\hline Asian & $0.031(.17)$ & $0.063(.24)$ & $0.054(.23)$ \\
\hline Has a Graduate Degree & $0.107(.31)$ & $0.156(.36)$ & $0.143(.35)$ \\
\hline Proportion of months employed since 1982 & $96.8(7.84)$ & $96.7(7.4)$ & $96.6(8.1)$ \\
\hline College Education Helpful & $0.617(.49)$ & $0.634(.48)$ & $0.628(.48)$ \\
\hline $\begin{array}{l}\text { Highest Level of Education Attained by Either } \\
\text { Parent }\end{array}$ & $6.34(2.56)$ & $6.82(2.6)$ & $6.85(2.6)$ \\
\hline Years of Experience at Current Job & $2.96(2.32)$ & $2.83(2.2)$ & $2.84(2.2)$ \\
\hline Percent of Drop-Outs from High School & $5.93(7.71)$ & $6.24(7.45)$ & $5.99(6.9)$ \\
\hline Female & $0.514(.500)$ & $0.467(.5)$ & $0.471(.5)$ \\
\hline Occupation Engineering Professional & $0.036(.185)$ & $0.062(.24)$ & $0.056(.23)$ \\
\hline Occupation Manager & $0.227(.42)$ & $0.249(.43)$ & $0.238(.43)$ \\
\hline Occupation Medical Professional & $0.070(.25)$ & $0.060(.24)$ & $0.064(.25)$ \\
\hline Occupation Legal Professional & $0.022(.15)$ & $0.036(.18)$ & $0.032(.18)$ \\
\hline Occupation Other Professional & $0.081(.27)$ & $0.063(.24)$ & $0.073(.26)$ \\
\hline Occupation Sales & $0.079(.27)$ & $0.096(.29)$ & $0.101(.30)$ \\
\hline Occupation School Teacher & $0.052(.22)$ & $0.036(.19)$ & $0.030(.17)$ \\
\hline Occupation Computer & $0.049(.22)$ & $0.06(.24)$ & $0.051(.22)$ \\
\hline Occupation non-computer technical & $0.022(.15)$ & $0.008(.09)$ & $0.015(.12)$ \\
\hline Occupation Physician & $0.011(.11)$ & $0.021(.15)$ & $0.024(.15)$ \\
\hline Has a Bachelor's Degree & $0.647(.48)$ & $0.72(.45)$ & $0.72(.45)$ \\
\hline Family Income in 1982 & $5.15(2.02)$ & $5.45(2.04)$ & $5.41(2.07)$ \\
\hline $\mathrm{N}$ & 1872 & 362 & 528 \\
\hline
\end{tabular}

1: denotes a "Best College" if the school in this category made the U.S. News list in at least 5 of the 7 years, 1983-1991

2: denotes a "Best College" if the school in this category made the U.S. News list in at least 2 of the 7 years, 1983-1991 
Table 3: Wage Equations

\begin{tabular}{|c|c|c|c|c|c|c|c|c|}
\hline Variable & Eqn. 1 & Eqn. 2 & Eqn. 3 & Eqn. 4 & Eqn. 5 & Eqn. 6 & Eqn. 7 & Eqn. 8 \\
\hline Personal SAT & $\begin{array}{l}.0005 * * * \\
(.0001)\end{array}$ & $\begin{array}{l}.0004 * * * \\
(.0001)\end{array}$ & $\begin{array}{l}.0004 * * * \\
(.0001)\end{array}$ & $\begin{array}{l}.0004 * * * \\
(.0001)\end{array}$ & $\begin{array}{l}.0004 * * * \\
(.0001)\end{array}$ & $\begin{array}{l}.0004 * * * \\
(.0001)\end{array}$ & $\begin{array}{l}0.0004 \\
(.0003)\end{array}$ & $\begin{array}{l}0.0004 \\
(.0003)\end{array}$ \\
\hline Black & $\begin{array}{l}.275^{* * * *} \\
(.094)\end{array}$ & $\begin{array}{l}.253 * * * \\
(.094)\end{array}$ & $\begin{array}{l}.302 * * * \\
(.106)\end{array}$ & $\begin{array}{l}.272 * * * \\
(.094)\end{array}$ & $\begin{array}{l}.268 * * * \\
(.094)\end{array}$ & $\begin{array}{l}.268 * * * \\
(.094)\end{array}$ & $\begin{array}{l}0.439^{*} \\
(.230)\end{array}$ & $\begin{array}{l}0.268 \\
(.175)\end{array}$ \\
\hline Years of Experience at Current Job & $\begin{array}{l}.044 * * * \\
(.010)\end{array}$ & $\begin{array}{l}.044 * * * \\
(.010)\end{array}$ & $\begin{array}{l}.039 * * * \\
(.011)\end{array}$ & $\begin{array}{l}.045 * * * \\
(.010)\end{array}$ & $\begin{array}{l}.045 * * * \\
(.010)\end{array}$ & $\begin{array}{l}.045 * * * \\
(.010)\end{array}$ & $\begin{array}{l}0.023 \\
(.024)\end{array}$ & $\begin{array}{l}-0.0009 \\
(.019)\end{array}$ \\
\hline Female & $\begin{array}{l}-.288 * * * \\
(.047)\end{array}$ & $\begin{array}{l}-.289 * * * \\
(.047)\end{array}$ & $\begin{array}{l}-.293 * * * \\
(.050)\end{array}$ & $\begin{array}{l}-.290 * * * \\
(.047)\end{array}$ & $\begin{array}{l}-.289 * * * \\
(.047)\end{array}$ & $\begin{array}{l}-.290 * * * \\
(.047)\end{array}$ & $\begin{array}{l}-.0117 \\
(.110)\end{array}$ & $\begin{array}{l}-0.254 * * \\
(.086)\end{array}$ \\
\hline Has a Bachelor's Degree & $\begin{array}{l}.236 * * * \\
(.051)\end{array}$ & $\begin{array}{l}.230 * * * \\
(.051)\end{array}$ & $\begin{array}{l}.252 * * * \\
(.054)\end{array}$ & $\begin{array}{l}.234 * * * \\
(.051)\end{array}$ & $\begin{array}{l}.235 * * * \\
(.051)\end{array}$ & $\begin{array}{l}.236 * * * \\
(.051)\end{array}$ & $\begin{array}{l}0.16 \\
(.129)\end{array}$ & $\begin{array}{l}0.176^{*} \\
(0.10)\end{array}$ \\
\hline Family Income in 1982 & $\begin{array}{l}.033 * * * \\
(.012) \\
\end{array}$ & $\begin{array}{l}.029 * * \\
(.012)\end{array}$ & $\begin{array}{l}.032 * * \\
(.013)\end{array}$ & $\begin{array}{l}.030 * * * \\
(.012) \\
\end{array}$ & $\begin{array}{l}.032 * * * \\
(.012) \\
\end{array}$ & $\begin{array}{l}.032 * * * \\
(.012)\end{array}$ & $\begin{array}{l}0.059^{*} \\
(.031)\end{array}$ & $\begin{array}{l}0.039 * \\
(.023)\end{array}$ \\
\hline $\begin{array}{l}\text { Research Expenditures per Faculty } \\
\text { Member at College Attended }\end{array}$ & & & $\begin{array}{l}.003 * * * \\
(.001) \\
\end{array}$ & & & & & \\
\hline $\begin{array}{l}\text { Attended a Private, non-sectarian, } \\
\text { College }\end{array}$ & & $\begin{array}{l}.207 * * * \\
(.064)\end{array}$ & & & & & & \\
\hline $\begin{array}{l}\text { Attended a private, Catholic, } \\
\text { college }\end{array}$ & & $\begin{array}{ll}.093 \\
(.093)\end{array}$ & & & & & & \\
\hline $\begin{array}{l}\text { Attended a Private, Protestant, } \\
\text { college }\end{array}$ & & $\begin{array}{l}-. .096 \\
(.078)\end{array}$ & & & & & & \\
\hline U.S. News Best College & & & & $\begin{array}{l}.081 \\
(.096)\end{array}$ & & & & \\
\hline $\begin{array}{l}\text { U.S. News Best National } \\
\text { University }\end{array}$ & & & & & $\begin{array}{l}.131 \\
(.136)\end{array}$ & $\begin{array}{l}.132 \\
(.136)\end{array}$ & $\begin{array}{l}-0.08 \\
(.158)\end{array}$ & $\begin{array}{l}-0.031 \\
(.144)\end{array}$ \\
\hline $\begin{array}{l}\text { U.S. News Best National Liberal } \\
\text { Arts College }\end{array}$ & & & & & $\begin{array}{l}.070 \\
(.234)\end{array}$ & & & \\
\hline $\begin{array}{l}\text { U.S. News Best Regional Liberal } \\
\text { Arts College }\end{array}$ & & & & & $\begin{array}{ll}.166 \\
(.384)\end{array}$ & & & \\
\hline $\begin{array}{l}\text { U.S. News Best Comprehensive } \\
\text { College }\end{array}$ & & & & & $\begin{array}{l}-.002 \\
(.165)\end{array}$ & $\begin{array}{l}.034 \\
(.085) \\
\end{array}$ & & \\
\hline Adjusted R-squared (N) & 0.146 & 0.151 & 0.161 & 0.159 & 0.159 & 0.159 & 0.08 & 0.11 \\
\hline $\mathrm{N}$ & 1872 & 1872 & 1872 & 1872 & 1872 & 1872 & 362 & 528 \\
\hline
\end{tabular}

$*$ = statistically significant at the 0.10 level $* *=$ statistically significant at 0.05 level; $* * *=$ statistically significant at 0.01 level; standard error in parentheses

\section{APPENDIX 1}

- $\quad$ Asian: dummy variable equal to 1 if the individual was Asian

- $\quad$ Bachelor's Degree: dummy variable equal to 1 if the individual attained a bachelor's degree

- $\quad$ Black: dummy variable equal to 1 if the individual was Black

- $\quad$ College education helpful in getting current job: dummy variable set equal to 1 if, when interviewed in 1992, the individual indicated he would not have been able to get his current job without the education he had received since high school.

- $\quad$ Family Income = family income in 1982. A categorical variable, divided by 8ths, where higher categories correspond to higher levels of income

- $\quad$ Female: dummy variable set equal to 1 if the individual is female.

- $\quad$ Graduate Degree: dummy variable equal to 1 if transcripts indicated the student had earned a master's, doctorate or professional degree. This dummy is also set equal to 1 if the student indicated he had received a master's, doctorate or professional degree, in contradiction to his transcript record, and the survey did not receive all of the transcripts requested.

- $\quad$ High School GPA: categorical variable indicating the grades the individual earned in high school. The smaller the value the higher grades the student earned 
- $\quad$ Highest level of education attained by either parent: a categorical variable, divided by 9ths, starting w/ 2, indicating the highest level of education achieved by either parent. The greater the variable the higher the level of education attained. The parent's separate levels of education were combined into this one variable due to the high number of missing observations on one of the parents.

- $\quad$ Hispanic: dummy variable equal to 1 if the individual was Hispanic

- In School: dummy variable equal to 1 if, when interviewed in 1992, the individual was taking undergraduate or graduate classes.

- $\quad$ LNINC: natural log of the income an individual earned in 1992

- Occupation computer: dummy variable equal to 1 if the individual's 1992 occupation is computer related, technical

- Occupation engineering professional: dummy variable equal to 1 if the individual's 1992 occupation is engineering professional

- Occupation legal professional: dummy variable equal to 1 if the individual's 1992 occupation is legal professional

- Occupation manager: dummy variable equal to 1 if the individual's 1992 occupation is government management, sales management, retail management, manufacturing management, or other management

- Occupation medical professional: dummy variable equal to 1 if the individual's 1992 occupation is medical professional

- $\quad$ Occupation physician: dummy variable equal to 1 if the individual's 1992 occupation is physician

- Occupation other professional: dummy variable equal to 1 if the individual's 1992 occupation is other professional

- $\quad$ Occupation sales: dummy variable equal to 1 if the individual's 1992 occupation is sales

- $\quad$ Occupation school teacher: dummy variable equal to 1 if the individual's 1992 occupation is school teacher

- Occupation non-computer technical: dummy variable equal to 1 if the individual's 1992 occupation is noncomputer related, technical

- $\quad$ Percent of high school drop-outs: percent of students who dropped out of the high school the individual attended

- $\quad$ Private, Catholic, College: dummy variable equal to 1 if the college the student attended was a private, catholic institution.

- $\quad$ Private, non-sectarian, college: dummy variable equal to 1 if the college the student attended was a private, nonsectarian institution.

- $\quad$ Private Protestant College: dummy variable equal to 1 if the college the student attended was a private, Protestant institution.

- $\quad$ Proportion of months employed since 1982: the proportion of months the individual has been employed since $6 / 82$ (the typical date of high school graduation)

- $\quad$ Research expenditures per faculty member: the 1982 dollar value of research expenditures (in thousands) reported by the college or university the individual attended per faculty member.

- SAT: score earned on the SAT or, if the SAT was not taken, score earned on the ACT converted into its SAT value.

- $\quad$ Undergraduate GPA: total undergraduate GPA. This is based on a 0-4.0 scale.

- Unemployed: dummy variable equal to 1 if, when interviewed in 1992, the individual was not working full-time or part-time, or was temporarily laid-off.

- $\quad$ Years of experience at current job: years experience, broken into twelfths, at the individual's current or most recent job.

Note: an individual could identify himself as having one of 29 different occupations. In this sample 30-35\% of the individuals had occupations other than those captured by the dummy variables.

\section{REFERENCES}

1. Belman, Dale and John S. Heywood. 1991. Sheepskin effects in the returns to education: An examination of women and minorities. The Review of Economics and Statistics. 73, pp. 720-724.

2. Brewer, Dominic J. and Ronald G. Ehrenberg. 1996. Does it pay to attend an Elite Private College? Evidence from the Senior High School Class of 1980. Research in Labor Economics. Vol. 15, pp 239-271. 
3. Brewer, Dominic J., Eric Eide, and Ronald G. Ehrenberg. 1996. Does it pay to attend an Elite Private College? Cross Cohort Evidence on the Effect of College Quality on Earnings. National Bureau of Economic Research Working Paper no. 5613, June.

4. Cooperative Institutional Research Program. 1987. The American Freshman: Twenty Year Trends, 19661985. The Higher Education Research Institute, Graduate School of Education, UCLA, January.

5. Filer, Randall Kieth. 1983. The Influence of Affective Human Capital on the Wage Equation. In Research in Labor Economics, vol. 4, edited by R. Ehrenberg. JAI Press.

6. Fox, Marc. 1993. Is it a Good Investment to Attend an Elite Private College? Economics of Education Review. Vol. 12, No. 2. pp. 137-151.

7. Griliches, Zvi. 1972. Education, income and ability. Journal of Political Economics 80 (3 pt. 2) S74-S103.

8. Jaeger, David, A. and Marianne E. Page. 1996. Degrees matter: New evidence on sheepskin effect in the returns to education. The Review of Economics and Statistics. 78 (4), pp. 733-739.

9. James, Estelle, Nabeel Alsalam, Joseph Conaty, and Duc-Le To. 1989. College Quality and Future Earnings: Where Should you send Your Child to College? American Economic Review. 79(2), pp. 247-252.

10. Loury, Linda Datcher and David Garman. 1995. College Selectivity and Earnings. Journal of Labor Economics. 13:2, pp. 289-308.

11. Monks, James and Ronald G. Ehrenberg. 1999. “The Impact of U.S. News and World Report College Rankings on Admissions Outcomes and Pricing Policies at Selective Private Institutions.” NBER Working Paper 7227.

12. Morgan, James N., and Greg J. Duncan. 1979. College Quality and Earnings. Research in Human Capital and Development. Vol. 1, pp. 103-121.

13. Owings, Stephanie. 1996. Higher Education as Screening or Human Capital? New Evidence. Unpublished manuscript.

14. Solmon, Lewis. 1973. The definition and impact of college quality. In Solmon \& Taubman, Does College Matter? New York: Academic Press.

15. Solmon, Lewis. 1975. The Definition of College Quality and its Impact on Earnings. Explorations in Economics Research, 2:537-587.

16. Solmon, Lewis, C., and Paul Wachtel. 1975. The effects on income of type of college attended. Sociology of Education. 48(winter), pp. 75-90.

17. Stecklow, Steve. 1995. Cheat Sheets: Colleges Inflate SATs and Graduation Rates in Popular Guidebooks. The Wall Street Journal. April 5, p. A1.

18. Tracy, Joseph and Joel Waldfogel. 1997. The Best Business Schools: A Market-Based Approach. Journal of Business. 70:1, pp. 1-31.

19. Wachtel, Paul. 1976. The effect on earnings of school and college investment expenditures. Review of Economics and Statistics. 58: 326-331.

20. Wales, Terence.1973. The effect of college quality on earnings: results from the NBER-Thorndike Data. Journal of Human Resources 8(3), pp. 306-317.

21. Weisbrod, Burton, and Peter Karpoff. 1968. Monetary returns of college education, student ability, and college quality. Review of Economics and Statistics 50, pp. 491-497.

22. Wise, David, A. 1975. Academic achievement and job performance. American Economic Review 65(3), pp. 350-366. 
NOTES 